\title{
Correction to: Design optimization of aircraft structures using virtual proving ground
}

\author{
Yuriy Gorskii $^{1}$ (D) $\cdot$ Petr Gavrilov $^{1} \cdot$ Georgiy Nikitin $^{1} \cdot$ Tatiana Pautova $^{1} \cdot$ Aleksandr Tamm $^{1}$
}

Published online: 22 July 2021

(C) Springer-Verlag London Ltd., part of Springer Nature 2021

\section{Correction to: The International Journal of Advanced Manufacturing Technology https://doi.org/10.1007/s00170-021-07355-1}

The article "Design optimization of aircraft structures using virtual proving ground", written by Yuriy Gorskii, Petr Gavrilov, Georgiy Nikitin, Tatiana Pautova and Aleksandr Tamm, was originally published electronically on the publisher's internet portal on 19 June 2021 without open access. With the author(s)' decision to opt for Open Choice the copyright of the article changed on 29 June 2021 to (C) The Author(s) 2021 and the article is forthwith distributed under a Creative Commons Attribution 4.0 International License, which permits use, sharing, adaptation, distribution and reproduction in any medium or format, as long as you give appropriate credit to the original author(s) and the source, provide a link to the Creative Commons license, and indicate if changes were made. The images or other third party material in this article are included in the article's Creative Commons license, unless indicated otherwise in a credit line to the material. If material is not included in the article's Creative Commons license and your intended use is not permitted by statutory regulation or exceeds the permitted use, you will need to obtain permission directly from the copyright holder. To view a copy of this license, visit http://creativecommons.org/licenses/by/4.0.

Publisher's note Springer Nature remains neutral with regard to jurisdictional claims in published maps and institutional affiliations.

The online version of the original article can be found at https://doi.org/ 10.1007/s00170-021-07355-1

Yuriy Gorskii

gorskij_yua@spbstu.ru; iurii.gorskii@gmail.com

Petr Gavrilov

gavrilov_pa@spbstu.ru

Georgiy Nikitin

g.nikitin@compmechlab.ru

Tatiana Pautova

pautova@compmechlab.ru

Aleksandr Tamm

tamm@spbstu.ru

1 Peter the Great St. Petersburg Polytechnic University, St.

Petersburg, Russia 